\title{
АНАЛІЗ МІЖНАРОДНИХ МОНІТОРИНГОВИХ ДОСЛІДЖЕНЬ І РЕФОРМ У ГАЛУЗІ ОСВІТИ: СВІТОВИЙ ДОСВІД ТА УКРАЇНСЬКИЙ КОНТЕКСТ
}

\author{
Світлана Дриль \\ аспірант Національного педагогічного університету імені М. П. Драгоманова, \\ м. Київ, Україна \\ ORCID ID 0000-0002-6870-2581 \\ s.b.dryl@gmail.com \\ Людмила Кухар
}

кандидат педагогічних наук, доцент кафедри комп'ютерної інженерії та освітніх вимірювань, Національний педагогічний університет імені

М. П. Драгоманова, м. Київ, Україна

ORCID ID 0000-0003-0093-4877

l.o.kuhar@npu.edu.ua

Анотація. У статті висвітлена проблема аналізу міжнародних моніторингових досліджень і реформ у галузі освіти: світовий досвід та український контекст. Результати дослідження довели, що зарубіжна програма дослідження формування соціально-емоційних навичок (Study of Social and Emotional Skills) є не менш важливою для подальшої ії реалізації й на Україні: для виявлення й оцінювання соціально-емоційних навичок школярів, прогнозування та корекції поведінки дітей, що впливає на подальшу суспільно-економічну інтеграцію та особистий розвиток. Зокрема, були наведені інструменти дослідження соціально-емоційних навичок, доменну соціально-емоційну модель особистості досліджуваних, показані зразки анкетних опитувань. Нами запропоновано залучити Україну до міжнародного проекту «Study of Social and Emotional Skills» у зв'язку 3 виявленою необхідністю як для держави, так і для учнів.

Ключові слова: освітні стандарти; PISA; Організація економічного дослідження та розвитку; міжнародні дослідження; соціально-емоційні навички.

Постановка проблеми в загальному вигляді. Оцінювання якості освіти набуває все більшого значення. Так, для держави це можливість підвищення конкурентоздатності міжнародних економічних відносин; для роботодавців кваліфікована підготовка спеціалістів, які вміють швидко адаптуватися до вимог суспільства й технологічних змін; для освітніх установ - дотримання вимог щодо освіченості згідно з Державними стандартами; для батьків і самих учнів спосіб вибору власного шляху розвитку та самовдосконалення. Свідченням цього став Указ Президента України від 12 січня 2015 року, у якому було схвалено Стратегію сталого розвитку «Україна - 2020» [9], де зазначено, що Україна візьме участь у міжнародному дослідженні якості освіти PISA та увійде до 50 кращих держав - учасниць такого дослідження. Відтак розпорядженням Кабінету Міністрів України від 04 лютого 2016 року № 72-р «Деякі питання 
участі України в міжнародному дослідженні якості освіти PISA - 2018» було прийнято рішення про реформування освіти та створення освітніх стандартів на підгрунті врахування міжнародного досвіду. Наказом Міністерства освіти i науки України від 26.01.2017 р. «Про підготовку в 2017 році до проведення міжнародного дослідження якості освіти PISA - 2018 в Україні» [11] було затверджено низку заходів, спрямованих на забезпечення підготовки та його проведення.

Аналіз останніх досліджень і публікацій. Деякі концептуальні засади міжнародних моніторингових проектів TIMSS, PISA, PIRLS розглядали у своїх працях Н. Бобак, О. Мартинюк, Н. Марочко [1]. О. Матвійчук порушувала питання про підвищення читацької грамотності серед учнів [3]. Г. Войтків, посилаючись на Державний стандарт базової і повної загальної середньої освіти, досліджує трьохрівневі компетентнісно зорієнтовані завдання PISA [4]. Результати європейського досвіду моніторингу якості освіти в межах міжнародних дослідницьких програм i визначення чинників успішності навчання школярів проаналізовано О. Пермяковою [5]. С. Оксамитна, А. Васильченко відзначають кореляцію результатів успішності від гендерних, соціально-економічних i культурних, шкільних освітніх систем країн i навчальних закладів [6].

С. Одайник у своїй науковій праці висвітлює етапи міжнародного дослідження PISA та наголошує на важливості його результатів для реального оцінювання здатності орієнтуватися п'ятнадцятирічних школярів у суспільному житті, керуючись шкільними знаннями [7]. Т. Вакуленко, С. Ломакович розкрили подальші результати реформування системи освіти після впровадження міжнародного оцінювання та оприлюднення його результатів у деяких країнах $\mathrm{CC}$ [8]. С. Дичок звернув увагу на міжнародне дослідження якості освіти в Польщі та Естонії [12]. Окремі аспекти досліджуваної проблеми знайшли відображення в працях С. Науменко, А. Головка та інших.

Проте виникає необхідність дослідження формування соціальноемоційних навичок (Study of Social and Emotional Skills) в Україні на індивідуальному та суспільному рівнях, що $\epsilon$ передумовою поліпшення якості освіти в контексті продовження Міжнародної програми PISA у зв'язку 3 виявленням залежності майбутнього соціально-економічного благополуччя від успішності навчання, зокрема для подальшого успішного навчання, соціальноекономічного прогресу, можливості подальшого працевлаштування, швидкої адаптації та інтегрування в суспільстві.

Формулювання цілей статті. Метою статті $\epsilon$ визначення ролі Міжнародного дослідження формування соціальних та емоційних навичок (Study of Social and Emotional Skills) у контексті українського та світового досвіду.

Результати дослідження. Інтелектуальний потенціал та індивідуальні якості значною мірою впливають на професійні досягнення в дорослому житті, 


\section{С. ДРИЛЬ, Л. КУХАР}

Аналіз міжнародних моніторингових досліджень і реформ у галузі освіти:

світовий досвід та український контекст

соціально-культурну інтеграцію та благополуччя, що закладаються ще змалечку та особливого розвитку набувають у шкільному віці. Так, соціально-емоційні навички взаємопов'язані з успішністю. Важливу роль для досягнення високого рівня життя відіграє діяльність самої держави: фінансування, макроекономічні показники, трудові ресурси. Водночас забезпечення якісної освіти та життя покладається на кожного громадянина, від якого залежить його ж ступінь матеріальних, культурних, фізичних і духовних показників: здоров’я, трудової зайнятості, рівня доходу, сім’ї, освіти, наявності власного житла і транспорту, активного дозвілля, задоволення життям.

Історія становлення досліджень у галузі освіти розпочалася ще в 1980 році 3 проведення Техаським Агентством освіти стандартизованого тестування «Texas Assessment of Basic Skills» базових навичок компетенцій із математики, читання і письма [13]. В освітній сфері за кордоном відбувалась значна кількість подій, які спричинили активне реформування освіти. Визначальні, на нашу думку, події наведено в таблиці [17].

Табличя 1

\section{Хронологія подій, що спричинили формулювання компетенцій для навчання необхідних упродовж життя}

\begin{tabular}{|c|c|}
\hline Рік & Подія (основні кроки) \\
\hline $\begin{array}{l}2000 \mathrm{p} . \\
\text { м. Лісабон }\end{array}$ & $\begin{array}{l}\text { Наголошено засіданням Європейської Ради про потребу } \\
\text { сформованості навичок упродовж життя. }\end{array}$ \\
\hline $\begin{array}{l}2001 \mathrm{p} . \\
\text { м. Стокгольм }\end{array}$ & $\begin{array}{l}\text { Затверджено Робочу програму } 3 \text { освіти та професійної підготовки, в якій } \\
\text { визначалися компетенції вивчення мов та розвиток підприємницької діяльності. }\end{array}$ \\
\hline $2002 \mathrm{p}$ & $\begin{array}{l}\text { Визначено Резолюцією Ради необхідності навчання від дошкільного аж до після } \\
\text { пенсійного віку. }\end{array}$ \\
\hline 2003 p. & $\begin{array}{l}\text { Доповнено еталонними компетенціями вміння читати, отримання повної } \\
\text { середньої освіти, навчання дорослих протягом життя. } \\
\text { Поставлено акцент на соціально-громадянській значущості, зокрема, рівності, } \\
\text { доброзичливості, повазі. }\end{array}$ \\
\hline $\begin{array}{l}2004 \text { p. } \\
\text { м. Маастрихт }\end{array}$ & $\begin{array}{l}\text { Розкрито невідповідність якості отриманої професійно-технічної освіти потребам } \\
\text { конкурентоздатному ринку праці. } \\
\text { Визначено ЄС потребу створення і забезпечення основних г громадянських } \\
\text { компетенцій, необхідних упродовж життя. }\end{array}$ \\
\hline $\begin{array}{l}2005 \mathrm{p} \text {. } \\
\text { м. Лісабон }\end{array}$ & $\begin{array}{l}\text { Визнано Лісабонською стратегією відсутності покращення навичок читання } \\
\text { п’ятнадцятирічних підлітків. }\end{array}$ \\
\hline $\begin{array}{l}2005 \mathrm{p} \\
\text { м. Брюссель }\end{array}$ & $\begin{array}{l}\text { Сформульовано Брюссельським засіданням Ради СС: професійні вимоги й } \\
\text { еталонні компетенції з урахуванням гендерної рівності. }\end{array}$ \\
\hline $\begin{array}{l}18 \text { грудня } \\
2006 \text { р. }\end{array}$ & $\begin{array}{l}\text { та визначено Європарламентом та Радою ЄС набору знань, умінь і } \\
\text { подальшої самореалізації та діяльності громадян. }\end{array}$ \\
\hline $\begin{array}{l}17 \text { січня } \\
2018 \text { р. }\end{array}$ & $\begin{array}{l}\text { Оновлено Рамкову програму Євросоюзу, схвалену Європарламентом та Радою } \\
\text { ЄС, визначено основні компетенції, необхідні для кожної молодої людини, які } \\
\text { послуговують гарантованому розвитку особистості та розширенню можливостей } \\
\text { упродовж життя. }\end{array}$ \\
\hline
\end{tabular}

Професіоналізм педагога: теоретичні й методичні аспекти. - Вип. 8. - Слов’янськ, 2018. 


\section{С. ДРИЛЬ, Л. КУХАР}

Аналіз міжнародних моніторингових досліджень і реформ у галузі освіти: світовий досвід та український контекст

Водночас Україною було зроблено деякі кроки. Реформування шкільної освіти, орієнтованої на дитиноцентризм, регламентується Концептуальними засадами Нової української школи від 17.08.2016 р., у яких визначено ключові компетентності для життя [14], що мають за мету сформувати патріотичну, всебічно розвинену особистість, спроможну до навчання впродовж усього життя.

Наказом Міністерства освіти і науки України № 1469 від 08.12.2016 року було затверджено в Міністерстві юстиції Положення про національний контактний пункт Рамкової програми Європейського Союзу з досліджень та інновацій «Горизонт 2020», що визначає тісну співпрацю у сфері наукових досліджень [15]. Закон України «Про освіту» [15], прийнятий 05 вересня 2017 року, покликаний забезпечити якісне навчання для подальшого самовдосконалення 3 метою прийняття відповідальних рішень для самореалізації, суспільної та трудової активності з одного боку, а 3 іншого зобов'язує проводити систематичне внутрішне оцінювання школярів як інструмент розвитку якості освіти. У статті 12 «Про повну загальну середню освіту» цього закону визначено сучасні ключові компетентності.

Для з'ясування спільних векторів розвитку освіти України та країн ЄС ми провели порівняльний аналіз основних документів і положень, що визначають ключові компетентності всебічно розвиненої особистості.

Таблиия 2

\section{Порівняльний аналіз ключових компетентностей різнобічно розвиненої особистості}

\begin{tabular}{|c|c|c|}
\hline Рамкова програма & $\begin{array}{l}\text { Закон України } \\
\text { про освіту }\end{array}$ & Нова українська школа \\
\hline $\begin{aligned} \checkmark & \text { Грамотність } \\
\checkmark & \text { Мовна компетентність } \\
\checkmark & \text { Математична, наукова, } \\
& \text { технологічна, інженерна } \\
& \text { компетентності } \\
\checkmark & \text { Цифрова компетентність } \\
\checkmark & \text { Особиста, соціальна та } \\
& \text { навчальна компетентності } \\
\checkmark & \text { Громадянська компетентність } \\
\checkmark & \text { Підприємницька } \\
& \text { компетентність } \\
\checkmark & \text { Компетентність культурної } \\
& \text { обізнаності,самовираження }\end{aligned}$ & $\begin{aligned} \checkmark & \text { Вільне володіння } \\
& \text { державною мовою } \\
\checkmark & \text { Здатність спілкуватися } \\
& \text { рідною та іноземними } \\
& \text { мовами } \\
\checkmark & \text { Математична } \\
& \text { компетентність } \\
\checkmark & \text { Компетентності в галузі } \\
& \text { природничих наук, техніки і } \\
& \text { технологій } \\
\checkmark & \text { Інноваційність } \\
\checkmark & \text { Екологічна компетентність } \\
\checkmark & \text { Інформаційно- } \\
& \text { комунікаційна } \\
& \text { компетентність } \\
\checkmark & \text { Навчання впродовж життя } \\
\checkmark & \text { Громадянські та соціальні } \\
& \text { компетентності } \\
\checkmark & \text { Культурна компетентність } \\
\checkmark & \text { Підприємливість } \\
& \text { фінансова грамотність та }\end{aligned}$ & $\begin{array}{l}\checkmark \text { Спілкування державною } \\
\text { мовою } \\
\checkmark \text { Спілкування іноземною } \\
\text { мовою } \\
\checkmark \text { Математична } \\
\text { компетентність } \\
\checkmark \text { Природничо-технологічна } \\
\checkmark \text { Інформаційно-цифрова } \\
\checkmark \text { Культурна компетентність } \\
\checkmark \text { Освіта впродовж життя } \\
\checkmark \text { Соціальна та громадська } \\
\checkmark \text { активність го го і } \\
\checkmark \text { Екологічна грамотність і } \\
\checkmark \text { здорове життя } \\
\checkmark \text { Ініціативність } \\
\quad \text { підприємливість }\end{array}$ \\
\hline
\end{tabular}


Водночас розпорядженням Кабінету Міністрів України № 72-р від 2016 року забезпечується участь України в міжнародному дослідженні якості освіти PISA-2018 для оцінювання здатності п'ятнадцятирічних підлітків застосовувати загальнонавчальні знання та вміння з математики (Mathematical Literacy), природничих наук (Science Literacy) та читання (Reading Literacy) у конкретних життєвих ситуаціях, що вимагають сформованості володіння навчальним матеріалом та інтелектуального й особистісного потенціалу, що $\epsilon$ достатніми для переходу в доросле суспільне життя [9].

Програма також передбачає на основі анкетування учнів, батьків і шкільної адміністрації виявлення факторів, що позначаються на їхньому суспільноекономічному положенні: розуміння і турбота батьків, матеріальний стан, навчальне вмотивування, зацікавлення та задоволення навчанням, кваліфікаційний рівень учителя, пошана до нього, шкільні навчальні плани та позашкільна освіта, контрольне оцінювання, особисті лідерські якості, кількість учнів у класі, міжособистісні взаємовідносини всередині класу та школи, комп'ютерну обізнаність тощчо.

Питанням якості освіти впродовж тривалого часу займається міжнародна Організація економічного співробітництва та розвитку (далі - ОЕСР) (Франція), що визначає політичну, економічну, соціальну діяльності задля надання рекомендацій, спрямованих на покращення їхньої ефективності. Зокрема, Андреасом Шлейхером, ініціатором Програми міжнародної оцінки студентів, розроблено та впроваджено Міжнародну програму оцінки освіти п'ятнадцятирічних учнів PISA у сфері читання, математики й науки (починаючи з 2000 року), а ОЕСР - Міжнародну програму оцінки компетенції для дорослих PIAAS (2008 - 2013, 2012 - 2016) від 16 до 65 років у більш ніж 40 країнах, що вимірює рівень знань і ключових навичок грамотності, читання, математики та використання інформаційно-комунікаційних технологій. Проміжною ланкою між цими програмами було TALIS (2008) - міжнародне дослідження, що проводило опитування вчителів і директорів шкіл про умови роботи.

Уперше Організація економічного співробітництва та розвитку зацікавилася дослідженням соціально-емоційних навичок лише у 2014 році у зв'язку 3 виявленням залежності майбутнього соціально-економічного благополуччя від успішності навчання. Це було наслідком робочих зустрічей груп експертів Германії, Іспанії, США, Нідерландів, Великобританії та Швеції (квітень 2007 року) в м. Сантандері (Іспанія) для обговорення знань, досвіду та результатів в області соціально-емоційної освіти. Наступне засідання для обговорення реального соціально-емоційного стану в Австралії, Канаді, Фінляндії, Португалії, Сингапурі було проведено 2011 року в межах створення програми «Відповідальна освіта». На міжнародному зібранні 2013 року експерти Аргентини, Австрії, Ізраїля, Норвегії та Південної Африки обмінялися новітніми методами, розробленими в цих країнах. Було опубліковано наукову працю «Fostering and measuring skills: improving cognitive and non-cognitive skills to 
promote lifetime succes» [19], у якій наголошується важливість закладання особистих якостей на ранній стадії дитячих і шкільних років. Ці риси вказують на змінність і спадковість навичок, які не можливо виміряти тільки тестами IQ або тестами досягнень. Для цього використовують опитування та звіти спостерігачів, анкети учасників досліджень, результати навчання в школі тощо.

Широкою популярністю користується психологічна таксономія «Великої п’ятірки» для визначення параметрів некогнітивних навичок, що регулюють поведінку при певних обставинах. Досліджено, що ефективність виконання завдань залежить від рис характеру, зусиль, когнітивних та некогнітивних навичок, стимулів, сильних і слабких сторін, причому з можливою компенсацією тих чи тих вимірів.

Водночас невміння проведення глибокого аналізу трансформує повноту навичок на інший вимір, у зв'язку з чим на основі кількарічного грунтовного вивчення літератури, концептуального й емпіричного аналізу ОЕСР розпочалося міжнародне дослідження «The Study on Social and Emotional Skills» (2016 - 2017 pp.), метою якого $є$ виявлення навичок учнів у соціально-емоційній сфері, що пов'язані з навчальними здобутками, школою, поведінкою та характеристиками учнів i студентів, громадським середовищем, сім'єю, психічно-фізичним здоров'ям, особистим благополуччям, антисоціальним проявом. Країнамиучасниками є Канада (Оттава), США, Колумбія (Манісалес, Богота), Італія (Рим), Росія, Португалія, Турція, Фінляндія (Хельсінкі), Південна Корея та Китай.

Так, (2017 - 2018 рр. - апробація, 2018 - 2019 - основна частина дослідження) з боку дітей вивчається соціально-демографічний фон, щоденні заняття, відносини з батьками та однолітками, добробут, шкільне життя, сприйняття соціально-економічних навичок. Зі сторони батьків досліджуються фактори впливу сімейного фону: навички, матеріальний стан, ставлення до дитини, стиль поведінки та особиста думка. 3 боку вчителів - соціально-емоційні навички, персональні дані педагогів, шкільні характеристики, практичний досвід, сприйняття навичок. Також увагу в дослідженні приділяють даним про навчальний заклад: принципам і правилам управління, клімату, ролі соціальноемоційних навичок у програмі навчання та їхнє сприйняття.

Важливість дослідження вищезазначених навичок полягає в їхньому щоденному прояві в міжособистісному спілкуванні з пересічними людьми, родинному колі, навчальних закладах, поза ними, позакласній діяльності, установі, де працюють. Отже, триангулятивний метод дозволить виявити навички, які характеризують поведінку учнів у школі, із батьками та однолітками.

Це дослідження є добровільним і базується на відомій структурній моделі «Велика п’ятірка», у якій вимірюються соціально-емоційні навички за психометричною шкалою Лікерта. Тестованим відводиться 40 хвилин для вираження згоди чи незгоди з варіантами відповідей із серії тверджень. 


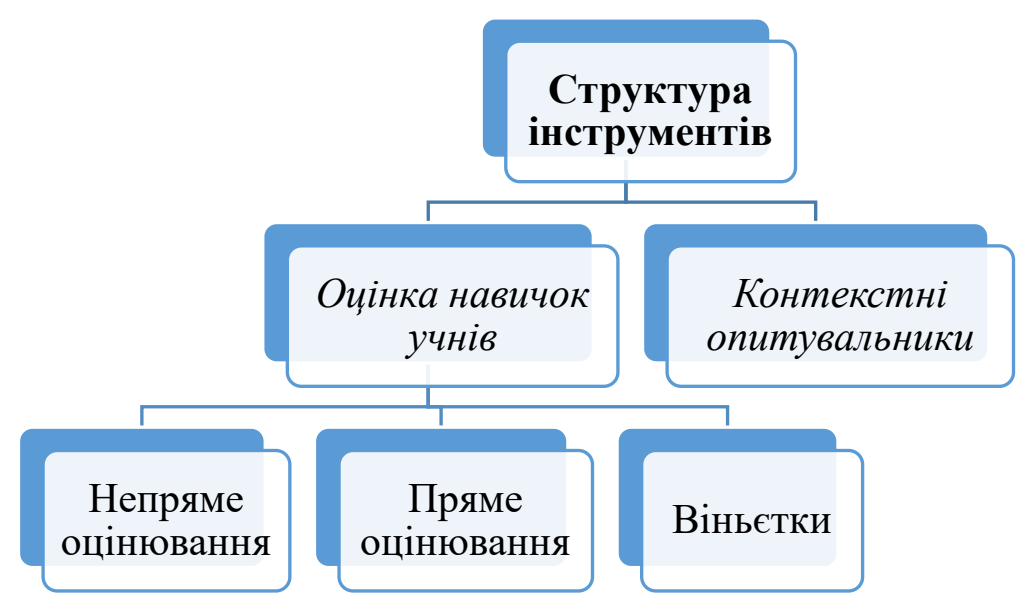

Рис.1. Структура інструментів дослідження сочіально-емочійних навичок

Наведемо деякі запитання, які ставлять учням у процесі анкетного опитування.

1. Як ви вважасте, чому ви ходите до школи?

А. Щоб легше знайти роботу

Б. Отримати широку культурологічну освіту

В. Тому що це обов'язково

Г. Тому що мені подобається

2. Якщо б ви перервали навчання в школі, як би ви використали час?
А. Допомагав би мамі
Б. Пас би худобу
В. Спав би
Г. Грався б
Д. Мені було б нудно
Е. Нічого не робив би
Ж.Не знаю
3. Навчався б все одно
И. Подорожував би

3. Як ви реагуєте на отримання негативної оцінки в школі?

А. Ви звинувачуєте вчителя

Б. Ви відчуваєте відповідальність

4. Якщо винним ви вважаєте вчителя, чи будете з ним розмовляти?
А. Так
Б. $\mathrm{Hi}$
5. Чи погоджуєтеся ви з такими твердженнями?
А. Абсолютно згоден (абсолютно згодна)
Б. Згоден (згодна)
В. Частково згоден (частково згодна)
Г. Не згоден (не згодна)
Д. Абсолютно не згоден (абсолютно не згодна) 
Я цікавлюся безліччю різних речей.

\section{Відкритість новому}

Я уникаю людей, які виглядають або поводяться не так, як всі.

У мене рідко виникають нові ідеї

Мені немає діла до поганих оцінок.

\section{Досягнення цілей}

Я обов'язково закінчую завдання.

Я часто роблю помилки через неуважність.

Якість цього дослідження грунтується на забезпеченні якості відповідей учнів, інформаційних шкільних звітів, індикаторів поведінки, анкет школярів, батьків, учителів, директорів шкіл та досліджень щодо шкільного оточення, друзів і сім'ї.

В Австрії соціально-емоційне навчання використовується в програмі початкової школи, де дітям допомагають формувати соціальні компетенції. 3 метою сприяння реалізації особистих і соціальних компетенцій у навчальних закладах місцевим урядом створено Центр розвитку особистості та соціального навчання. Пізніше були запроваджені проекти «Здоров'я» та «Емоційна освіта», спрямовані на зміцнення фізичного і духовного здоров'я. Інші програми мали за мету попередження й уникнення агресивної поведінки та залякування учнів через Internet.

У Фінляндії соціальна та емоційна освіта вважається еталоном для дітей $\mathrm{i}$ дорослих у всіх навчальних закладах. Найвідоміші програми спрямовані на емоційне розуміння, саморегуляцію та здоровий розвиток («Kokkonen», «Tunnemuksu»). «Cacciatore», «The KiVa Antibullying Programme» спрямовані на зменшення та запобігання агресивній поведінці в дітей.

У Німеччині навчальні програми зосереджені на співпереживанні, контролі імпульсів та управлінні гнівом. Німецька адаптація австралійської програми «MindMatters» була визнана ефективною в розвитку навичок спілкування. Загальношкільна програма психічного здоров'я, розвитку соціальних і комунікативних навичок «Erwachen werden» покликана надати інформацію про зловживання наркотичними речовинами та жорстокого поводження.

В Ірландії навчання соціально-емоційних навичок входить до комплексної програми «Соціальні, особисті навички та охорона здоров'я» в початковій і середній освіті, до яких, зокрема, відносяться самосвідомість, емоційне вираження, взаємовідносини 3 іншими, вирішення конфліктів, самооцінка, критичне мислення, фізичне та психічне здоров'я. Було введено в школах формування соціально-емоційних компетенцій на кожному навчальному предметі. Створено Національну програму розповсюдження Концепції принципів поширення психічного здоров'я в школах, Програму «Friends for life», спрямовану на допомогу учням в боротьбі з негативними почуттями тривоги та страху, зміцнення самооцінки. 
В Італії шкільні навчальні програми, що відповідають вимогам $\mathrm{CC}$, активно сприяють розвитку особистих і міжособистісних компетенцій учнів та вчителів, заохочують школярів до активної громадської позиції, розвитку критичного мислення. Навчальна програма «Miur» подає детальний опис соціально-емоційних компетенцій дітей різних вікових груп. У 2007 році Національний інститут здоров'я (Рим) реалізував програму «Психічного здоров'я». Інші програми, що були впроваджені в школах і дитячих садках, мали на меті покращення поведінки дітей.

У Швеції у 2000 році уряд ухвалив національний план розвитку охорони здоров'я, де зміцнення психічного здоров'я набуло особливого значення для дітей, підлітків та осіб із психічними розладами. Так, шведська програма соціально-емоційного навчання призначена для дітей від дошкільного віку аж до старшої середньої школи, тому достатньо часто використовується в школах. У навчальних закладах існує декілька програм зі зниження «дідівщини» i ризикованої поведінки.

У Росії розробляються авторські методики розвитку емоційного інтелекту та соціальної компетентності для шкіл. Професор Університету прикладних наук Давід Антоньяцца проводить практичні курси розвитку соціально-емоційної сфери дітей, методів взаємодії з батьками та впроваджує цю програму в навчальні заклади. Він є основоположником технології соціально-емоційного навчання (SEL) в школах Швейцарії. Так, Фондом «Вклад у майбутнє» було створено програму «Соціальний та емоційний інтелект», спрямовану на впровадження освітніх програм для дітей, особистого і професійного розвитку вчителів, сучасного освітньо-виховного середовища, розробку інноваційних стандартів навчання, оцінювання соціально-емоційної компетентності учнів і вчителів. Наприклад, функціонує Академія Монсиків - дитячий центр розвитку емоційного інтелекту від 1 до 13 років, де діти за допомогою мультиплікаційних персонажів навчаються розуміти себе, із легкістю засвоювати навчальний матеріал, співпрацювати 3 іншими, формуючи стресостійкість, навички вирішення конфліктів, досягнення мети, адаптації до нового.

За даними міжнародних досліджень, у 2010 році в Канаді відсутність соціально-емоційної регуляції спричинило серйозні проблеми в дітей у підлітковому віці, що пов'язані з розладами психічно-емоційного стану на фоні депресій, тривоги, порушень сну та залякування (44\% дівчаток і 28\% хлопчиків серед 10 класів). 45\% дівчат і 48\% хлопців відчули на собі знущання з боку однолітків і хуліганів. Дослідження визначили проблеми поведінки учнів як одні 3 ключових чинників, що призводять до стресових ситуацій і вигорання вчителів. Так, 2010 року 23\% канадської молоді у віці від 18 до 19 років не закінчили середню школу.

Опитування групи респондентів із науковців, програмістів і фінансистів вказало на причини необхідності розвитку соціально-емоційних навичок: зростання шкільного насильства та психічні захворювання. У рамках навчання 
соціально-емоційних навичок у Канаді створено спеціальні програми для формування компетентності вчителів, що спрямовані на покращення взаємовідносин між учнями, ефективного управління класом, для засвоєння відповідно до віку соціальних і емоційних навичок. Розроблені програми станом на 2013 рік сприймалися вчителями як перенавантаження, бо вчителі мали самостійно інтегрувати та впроваджувати їх.

В Америці проведено близько 200 досліджень після впровадження програм формування соціально-емоційних навичок, унаслідок чого виявили покращення соціальної поведінки, ставлення до себе та до оточення, академічної успішності, хоча й зміни були не стійкими з часом. Зменшення кількості та частоти вживання наркотиків, на жаль, не відбулося [23].

У зв'язку з посиленням зацікавлення до соціальних та емоційних навичок, їхнього впливу на особисту успішність та психофізіологічне здоров'я у 2016 році було видано довідник «Handbook of Social and Emotional Learning. Research and Practice» [21] для суспільної класифікації програм навчання дітей дошкільного віку, початкової, середньої та вищої школи, а також для студентів-інвалідів, стосунків учителя - учня, партнерських програм між школою та сім'єю, післяшкільного програмування та SEL, ювенальної юстиції та населення.

Висновки 3 дослідження і перспективи подальших розвідок у цьому напрямі. Отже, Україні надзвичайно важливо брати участь у Міжнародних стандартах педагогічних досліджень для отримання загальної картини практичного застосування і порівняння ефективності навчання на національному та міжнародному рівнях, що дасть змогу отримати індивідуальні, сімейні та шкільні чинники, що сприятимуть розвитку соціально-емоційних навичок громадян i дозволять розробникам освітньої та соціальної політики відслідковувати й удосконалювати необхідні навички. У рамках подібних досліджень відпрацьовуються нові методики й освітні технології, створюються підручники, оновлюються програми підвищення професійної майстерності, накопичується досвід проведення подібних досліджень, переймаючи його в кращих світових розробників.

Перспективи подальших досліджень вбачаємо у: залученні Організації економічного співробітництва та розвитку 3 подальшою координацією досліджень формування соціально-емоційних навичок в Україні; державному фінансуванні цієї програми; створенні спеціальних служб для проведення роботи з учнями з соціально-емоційного розвитку для здатності розуміння своїх емоцій і думок, що впливають на поведінку та взаємовідносини із суспільством.

\section{СПИСОК ВИКОРИСТАНИХ ДЖЕРЕЛ}

1. Бобак, Н. В., Мартинюк, О. В. і Марочко, Н. М. (1994). Моніторинг якості освіти: міжнародний досвід. Луцьк, Україна: Волин. ін-т післядиплом. пед. освіти.

2. Рамкова програма СС оновлених ключових компетентностей. (17 січня 2018 року) Взято 3 http://dlse.multycourse.com.ua/ua/page/15/53 


\section{С. ДРИЛЬ, Л. КУХАР}

Аналіз міжнародних моніторингових досліджень і реформ у галузі освіти: світовий досвід та український контекст

3. Матвійчук, О. С. (2017). Деякі питання підвищення читацької грамотності школярів. Київ, Україна: Бібліосвіт: інформ. вісн. 3 (63). Взято 3 http://elibrary.kubg.edu.ua/id/eprint/21331/1/O_Matviichuk_BS_3_63_2017_IPPO.pdf

4. Chernyshenko, O.M., Kankaraš and F. Drasgow. (2018). "Social and emotional skills for student success and wellbeing: Conceptual framework for the OECD study on social and emotional skills". OECD Education Working Papers, No. 173, OECD Publishing, Paris. Взято 3 http://dx.doi.org/10.1787/db1d8e59-en

5. Войтків, Г. В. (2017). Використання компетентнісно зорієнтованих завдань у форматі Pisa 3 метою формування ключових компетенцій. Кіровоград, Україна: Наукові записки РВВ КДПУ ім. В.Винниченка. № 11 (IV), 28-31.

6. Пермякова, О.Г. (2011). Моніторинг якості навчання в європейських країнах у контексті міжнародних порівняльних досліджень (друга половина XX століття). Наукові записки Тернопільського національного педагогічного університету ім. В. Гнатюка. Сер. Педагогіка. Терешук Г. (ред.) № 2, 224-229.

7. Оксамитна, С. М. і Васильченко, А. А. (2009). Соціальна диференціація освітніх можливостей за результатами міжнародного проекту PISA: досвід для України. Наукові записки НаУКМА. Том 96: Сочіологічні науки, 13-21.

8. Одайник, C. Ф. (2017). Рisa - невід’ємна частина системи оцінювання якості освіти в Україні. Таврійський вісник освіти. 1 (57), 33-38.

9. Вакуленко, Т. і Ломакович, С. (б.д.). PISA 2018: Що отримає Україна? Взято з: http://education-ua.org/ua/porivnyalna-pedagogika/818-pisa-2018-shcho-otrimae-ukrajina

10. Указ Президента України «Про Стратегію сталого розвитку Україна - 2020» № 5/2015 (2015, 12 січня). Взято 3 http://zakon4.rada.gov.ua/laws/show/5/2015

11. Розпорядження Кабінету Міністрів України «Деякі питання участі України у міжнародному дослідженні якості освіти Pisa - 2018» № 72-p (2016, 04 лютого). Взято 3 https://www.kmu.gov.ua/ua/npas/248816832

12. Наказ МОН України «Про підготовку в 2017 році до проведення міжнародного дослідження якості освіти Pisa - 2018 в Україні». (2017, 26 січня) Взято 3 http://osvita.ua/legislation/Ser_osv/54197/

13. Дичок, C. М. (2017). Дослідження Рisa: Міжнародний досвід Таврійський вісник освіти. № 1 (57), 13-19.

14. Texas Assessment of Basic Skills. (б.д.). Взято 3 https://en.wikipedia.org/wiki/Texas_Assessment_of_Basic_Skills

15. Нова українська школа. Концептуальні засади реформування середньої школи.

(б.д.). Взято 3 https://www.kmu.gov.ua/storage/app/media/reforms/ukrainska-shkolacompressed.pdf

16. Наказ МОН України "Про затвердження Положення про національний контактний пункт Рамкової програми Європейського Союзу з досліджень та інновацій «Горизонт 2020» № 1469. (2016, 08 грудня) Взято 3 https://xn--80aagahqwyibe8an.com/ukrajini-mon/nakaz-vid08122016-1469-pro-zatverdjennya-2016-47461.html

17. Закон України «Про освіту». (2017). Відомості Верховної Ради Украӥни, 38-39 (с. 380). Взято з http://zakon5.rada.gov.ua/laws/show/2145-19

18. Рекомендація 2006/962/СС Європейського Парламенту та Ради (СС) «Про основні компетенції для навчання протягом усього життя». (2006, 18 грудня). Взято 3 http://zakon.rada.gov.ua/laws/show/994_975

19. Порівняльний перелік ключових компетентностей ЄС. Освіта на основі життєвих навичок. Взято з http://dlse.multycourse.com.ua/ua/page/15/53\#1

20. Tim Kautz, James J. Heckman, Ron Diris, Bas ter Weel \& Lex Borghans. (2018). Fostering and measuring skills: improving cognitive and non-cognitive skills to promote lifetime 
Аналіз міжнародних моніторингових досліджень і реформ у галузі освіти: світовий досвід та український контекст

success Взято 3 http://www.oecd.org/education/ceri/Fostering-and-Measuring-Skills-ImprovingCognitive-and-Non-Cognitive-Skills-to-Promote-Lifetime-Success.pdf

21. The Study on Social and Emotional Skills - About the Study. Взято 3 http://www.oecd.org/education/ceri/study-on-social-and-emotional-skills-the-study.htm

22. Handbook of Social and Emotional Learning. Research and Practice. Взято 3 https://www.amazon.co.uk/Handbook-Social-Emotional-Learning-Research/dp/1462520154

23. Strengthening Social and Emotional Education as a Core Curriculum Area across the EU. (2018, February). DOI: 10.2766/456730

24. New International SEL Report Social and Emotional Education: An International Analysis. (2013). Взято 3 http://www.ncflb.com/wp-content/uploads/2013/02/SEL-worldwide.pdf

\title{
АНАЛИЗ МЕЖДУНАРОДНЫХ МОНИТОРИНГОВЫХ ИССЛЕДОВАНИЙ И РЕФОРМ В ОБЛАСТИ ОБРАЗОВАНИЯ: МИРОВОЙ ОПЫТ И УКРАИНСКИЙ КОНТЕКСТ
}

\author{
Светлана Дрыль \\ Аспирант Национального педагогического университета им. М.П. Драгоманова \\ г. Киев, Украина \\ ORCID ID 0000-0002-6870-2581 \\ s.b.dryl@gmail.com \\ Людмила Кухар
}

Кандидат педагогических наук, доцент кафедры компьютерной инженерии и образовательных измерений Национальный педагогический университет им. М. П. Драгоманова, г. Киев, Украина

ORCID ID 0000-0003-0093-4877

l.o.kuhar@npu.edu.ua

Аннотация. В статье освещена проблема анализа международных мониторинговых исследований и реформ в области образования: мировой опыт и украинский контекст. Результаты исследования показали, что зарубежная программа исследования формирования социально-эмоциональных навыков (Study of Social and Emotional Skills) не менее важна для дальнейшей реализации и на Украине: для выявления и оценки социально-эмоциональных навыков школьников, прогнозирования и коррекции поведения детей, - влияет на дальнейшую социально-экономическую интеграцию и личностное развитие. В частности, были приведены инструменты исследования социально-эмоциональных навыков, доменную социально-эмоциональную модель личности испытуемых, показаны образцы личных опросников. Нами предложено привлечь Украину к международному проекту «Study of Social and Emotional Skills» в связи с выявленной необходимостью как для государства, так и для учащихся.

Ключевые слова: образовательные стандарты; PISA; Организация экономического исследования и развития; международные исследования; социально-эмоциональные навыки.

\section{ANALYSIS OF THE INTERNATIONAL MONITORING RESEARCH AND REFORM IN EDUCATION: INTERNATIONAL EXPERIENCE AND UKRAINIAN CONTEXT}


Аналіз міжнародних моніторингових досліджень і реформ у галузі освіти: світовий досвід та український контекст

\author{
Svitlana Dryl \\ Postgraduate Student of the National Pedagogical Dragomanov University, \\ Kyiv, Ukraine \\ ORCID ID 0000-0002-6870-2581 \\ s.b.dryl@gmail.com \\ Liudmyla Kuhar \\ $\mathrm{PhD}$ in Pedagogics, Associate Professor of the Computer Engineering and \\ Educational Measurements Department \\ National Pedagogical Dragomanov University, Kyiv, Ukraine \\ ORCID ID 0000-0003-0093-4877 \\ l.o.kuhar@npu.edu.ua
}

\begin{abstract}
The article deals with the problem of the analysis of international monitoring studies and reforms in the field of education: world experience and the Ukrainian context. The analysis of publications shows that domestic researchers in their scholarly works describe the projects of international evaluation of the education quality introduced in Ukraine and abroad for discovering the differences in the systems of education at the national and international levels, ascertaining the factors that influence the students' achievement. In particular, the comparative analysis of subjects of the natural and mathematical cycle of primary and secondary schools (TIMSS); the level and quality of reading of popular science and art texts, the understanding of reading by primary school students (PIRLS); ability to involve fifteen-year-olds to receive school reading, mathematical, science-related subjects (Pisa).

The results of the study have shown that the foreign study program on studying social and emotional skills is of no less importance for further implementation in Ukraine, influencing further socio-economic integration and personal development. In particular, the research tools of the socioemotional skills, the domain social and emotional model of the personality of the subjects under study, were determined, and samples of questionnaires were shown. We are invited to bring Ukraine to the international project "Study of Social and Emotional Skills" in connection with both the state and students' needs.

It's extremely important for Ukraine to participate in International Standards of pedagogical researches for getting the general view of practical implementation and comparing education effectiveness at national and international levels that gives an opportunity to obtain individual, family and school factors which contribute to citizens' social and emotional skills. Within such researches new methodologies and educational technologies are worked out; new textbooks are created; the curriculum is improved; the experience of carrying out these researches is accumulated.
\end{abstract}

Key words: Educational Standards; Pisa; Organization for Economic Research and Development; International Studies; Socio-Emotional Skills.

\title{
REFERENCES (TRANSLATED AND TRANSLITERATED)
}

1. Bobak, N.V., Martyniuk, O.V. i Marochko, N.M. (1994). Quality Education Monitoring: International Experience. Lutsk, Ukraina: Volyn. in-t pisliadyplom. ped. osvity.

2. EU Framework Program for updated key competencies. (2018, January 17). Retrieved from http://dlse.multycourse.com.ua/ua/page/15/53

3. Matviichuk, O. Ie. (2017). Some issues raise student literacy. Kyiv, Ukraina: Bibliosvit: inform. visn. 3 (63). Retrieved http://elibrary.kubg.edu.ua/id/eprint/21331/1/O_Matviichuk_BS_3_63_2017_IPPO.pdf

4. Chernyshenko, O.M., Kankaraš \& F. Drasgow (2018), "Social and emotional skills for student success and wellbeing: Conceptual framework for the OECD study on social and emotional skills". OECD 


\section{С. ДРИЛЬ, Л. КУХАР}

Аналіз міжнародних моніторингових досліджень і реформ у галузі освіти: світовий досвід та український контекст

Education Working Papers, No. 173, OECD Publishing, Paris. Retrieved from http://dx.doi.org/10.1787/db1d8e59-en

5. Voitkiv H. V. (2017). Use of Competency-Oriented Tasks in Pisa Format to Create Key Competencies. Kirovohrad, Ukraina: Naukovi zapysky RVV KDPU im. V.Vynnychenka. 11 (IV), $28-31$.

6. Permiakova, O. H. (2011). Monitoring the quality of education in European countries in the context of international comparative studies (second half of the twentieth century). Naukovi zapysky Ternopilskoho natsionalnoho pedahohichnoho universytetu im. V. Hnatiuka. Ser. Pedahohika, 2, 224-229.

7. Oksamytna, S. M. \& Vasylchenko, A. A. (2009). Social differentiation of educational opportunities by the results of the international project PISA: experience for Ukraine.: Naukovi zapysky NaUKMA. Tom 96: Sotsiolohichni nauky, 13-21.

8. Odainyk, S. F. (2017). Pisa is an integral part of the education quality assessment system in Ukraine. Tavriiskyi visnyk osvity, 1 (57), 33-38.

9. Vakulenko, T. \& Lomakovych, S. (n.d.). PISA 2018: What will Ukraine get? Retrieved from http://education-ua.org/ua/porivnyalna-pedagogika/818-pisa-2018-shcho-otrimae-ukrajina

10.Decree of the President of Ukraine "On the Strategy of Sustainable Development Ukraine 2020" No. 5/2015. (2015, January 12). Retrieved from http://zakon4.rada.gov.ua/laws/show/5/2015

11. Order of the Cabinet of Ministers of Ukraine "Some Issues of Ukraine's Participation in the International Study on the Quality of Education in Pisa - 2018» № 72-p (2016, 04 February) Retrieves from: https://www.kmu.gov.ua/ua/npas/248816832

12. Order of the Ministry of Education of Ukraine "On Preparation in 2017 for the International Study on the Quality of Education Pisa - 2018 in Ukraine". (2017, January 26). Retrieved from http://osvita.ua/legislation/Ser_osv/54197/

13.Dychok, S. M. (2017). Pisa Research: International Experience. Tavriiskyi visnyk osvity, 1 (57), $13-19$.

14.Texas Assessment of Basic Skills. Retrieved from https://en.wikipedia.org/wiki/Texas_Assessment_of_Basic_Skills

15.New Ukrainian School. Conceptual Principles of Reforming High School. Retrieved from https://www.kmu.gov.ua/storage/app/media/reforms/ukrainska-shkola-compressed.pdf

16. Order of the Ministry of Education and Science of Ukraine "On Approval of the Regulation on the National Contact Point of the European Union Research and Innovation Framework Program" Horizon 2020. No. 1469. (2016, December 08). Retrieved from: https://xn--80aagahqwyibe8an.com/ukrajini-mon/nakaz-vid08122016-1469-pro-zatverdjennya-2016-47461.html

17.Law of Ukraine "On Education". (2017). Vidomodti Verkhovnoi rady, 38-39. Retrieved from http://zakon5.rada.gov.ua/laws/show/2145-19

18. Recommendation 2006/962 / EC of the European Parliament and of the Council (EU) "On core competences for lifelong learning”. (2006, December 18). Retrieved from: http://zakon.rada.gov.ua/laws/show/994_975

19.Comparative list of key competencies of the EU. Osvita na osnovi zhyttievykh navychok. Retrieved from http://dlse.multycourse.com.ua/ua/page/15/53\#1

20.Tim Kautz, James J. Heckman, Ron Diris, Bas ter Weel \& Lex Borghans. (2018). Fostering and measuring skills: improving cognitive and non-cognitive skills to promote lifetime success. Retrieved from: http://www.oecd.org/education/ceri/Fostering-and-Measuring-Skills-Improving-Cognitive-and-Non-

Cognitive-Skills-to-Promote-Lifetime-Success.pdf

21.The Study on Social and Emotional Skills - About the Study. Retrieved from http://www.oecd.org/education/ceri/study-on-social-and-emotional-skills-the-study.htm

22.Handbook of Social and Emotional Learning. Research and Practice. Retrieved from https://www.amazon.co.uk/Handbook-Social-Emotional-Learning-Research/dp/1462520154

23. Strengthening Social and Emotional Education as a Core Curriculum Area across the EU. (2018, February). DOI: $10.2766 / 456730$

24. New International SEL Report Social and Emotional Education: An International Analysis. (2013). Retrieved from http://www.ncflb.com/wp-content/uploads/2013/02/SEL-worldwide.pdf

\section{Матеріали надійшли до редакції 30.11.2018 p.}

